J. Clin. Chem. Clin. Biochem.

Vol. 24, 1986, pp. $221-225$

(C) 1986 Walter de Gruyter \& Co.

Berlin - New York

\title{
Monitoring of Urinary Proteins by SDS Electrophoresis in Kidney Transplant Patients
}

\author{
By A. Lapin, H. Zyman, F. Gabl \\ Institut für Klinische Chemie und Laboratoriumsdiagnostik
}

H. Kopsa and J. Zazgornik

I. Medizinische Universitätsklinik

Medizinische Fakultät, Universität Wien, Vienna, Austria

(Received September 28/November 29, 1985)

Summary: Sodium dodecyl sulphate (SDS) electrophoresis of urinary proteins was used routinely for monitoring more than 80 kidney transplant recipients as out-patients during one year. Special attention was paid to the question of whether this method can help the clinician to differentiate between a graft rejection reaction and Cyclosporin A-induced nephrotoxic damage. Two cases are presented showing the time course of proteinuric patterns together with serum creatinine, total urinary protein and, in one case, the blood level of Cyclosporin A. Changes of proteinuric patterns signalled the start of rejection and/or nephrotoxicity. A homogeneous collective of 33 kidney recipients (first transplantation) with chronic glomerulonephritis as a basic disease was specially selected. In this collective, the distribution of proteinuric patterns among patients and its dependence on immunosuppresive therapy was investigated. During the observation period of 7 months, two proteinuric patterns, "tubular" and "mixed weak", were found exclusively in Cyclosporin Atreated patients. We ascribe this finding to nephrotoxic effect of Cyclosporin A. We found the SDS electrophoresis of urinary proteins to be a useful, non-invasive method for monitoring Cyclosporin A-treated kidney transplant patients.

\section{Überwachung von Harnproteinen mit SDS-Elektrophorese bei nierentransplantierten Patienten}

Zusammenfassung: Die Natriumdodecylsulfat-(SDS-) Elektrophorese von Harnproteinen wird seit einem Jahr zur routinemäßigen Überwachung von mehr als 80 ambulanten Nierentransplantierten angewendet. Insbesondere sollte geklärt werden, ob diese Methode für den Kliniker eine Hilfe beim Erkennen und der Differentialdiagnose zwischen Cyclosporin A-induzierter nephrotoxischer Einwirkung und Abstoßungsreaktion bietet. Es wurden zwei Fälle präsèntiert, bei denen neben zeitlichen Änderungen des Proteinuriemusters auch Verläufe von Kreatinin im Serum, Protein im Harn und, in einem Fall, Konzentration von Cyclosporin A im Blut dargestellt sind. Änderungen im Verlauf des Proteinuriemusters signalisierten jeweils beginnende Abstoßungsreaktionen bzw. nephrotoxische Einwirkungen von Cyclosporin A. Ein homogenes Kollektiv von 33 Nierentransplantierten (erste Transplantation) mit chronischer Glomerulonephritis als Basiserkrankung wurde speziell ausgesucht. Es wurde in Abhängigkeit von immunsuppresiver Therapie die Verteilung des jeweiligen Proteinuriemusters auf die einzelnen Patienten untersucht. In 7 Monaten Beobachtungszeit wurden bei den Cyclosporin A-behandelten Patienten exklusiv zwei Proteinuriemuster gefunden: „tubulär“ und "gemischt - schwach". Wir schreiben diesen Befund der Cyclosporin A-induzierten nephrotoxischen Einwirkung zu. Wir fanden die SDS-Elektrophorese von Harnproteinen als eine wertvolle Methode, die hilfreich bei nicht-invasiver Überwachung von nierentransplantierten Patienten eingesetzt werden kann. 


\section{Introduction}

The immunosupressant "Cyclosporin A" (cyclosporin) is widely used to prevent allograft rejection of organ transplants $(1,2)$. However, in view of the danger of serious side effects, it is necessary to measure the circulating levels of cyclosporin, in order to adjust the dosage to the optimal level $(3,4)$. The nephrotoxic side effect of cyclosporin is a most dangerous complication in kidney transplantation and therefore requires special attention $(4-8)$. The decision as to whether graft rejection and/or nephrotoxicity are responsible for the restriction of the functionning of the transplanted kidney is a current clinical problem (8). Sodium dodecyl sulphate (SDS) electrophoresis of urinary proteins can be useful for the detection of cyclosporin-induced nephrotoxicity. This method provides information about the distribution of molecular weights of proteins in pathological urines. The molecular weight spectrum of urinary proteins is, to $a_{i}$ large extent, indicative of the affected part of the glomerulo-tubular apparatus of the kidney $(9,10)$. High molecular weight proteins are assigned to glomerular damage, low molecular weight proteins to tubular damage. SDS electrophoresis permits continuous and non invasive monitoring, and is especially suitable for detecting and distinguishing between changes in proteinuric patterns, which indicate the onset of damage due either to cyclosporin-induced nephrotoxic damage, or to a rejection.

\section{Materials and Methods}

\section{Patients}

We have used SDS electrophoresis of urinary proteins routinely over a period of one year for the weekly check up of kidney graft recipients as out patients of our nephrological unit. More than 80 renal transplant patients have been examined in this way. From these, a homogeneous group was selected, who had received only one transplant and whose original complaint had been chronic glomerulonephritis (tab. 1, top). Their urines were analysed by SDS electrophoresis at 1 to 4 week intervals during 7 months. Seventeen of these patients were treated with low doses of steroids and cyclosporin and another 16 patients recieved conventional immunosupressive therapy consisting of azathiaprine and prednisolone.

\section{Cyclosporin dosage}

We started with a daily intravenous cyclosporin dose of $5 \overline{\mathrm{mg}}$ / $\mathrm{kg}$ body weight, given continuously during the first $3-5$ days after surgery. This regimen was changed to an oral dose of 15 $\mathrm{mg} / \mathrm{kg}$ body weight per day divided in 2 or 3 equal portions. Depending on the cyclosporin concentrations in the blood the daily cyclosporin dose was then reduced to a maintenance dose of $5-8 \mathrm{mg} / \mathrm{kg}$. The conventional therapy consisted of azathioprine $(2 \mathrm{mg} / \mathrm{kg} \cdot$ day) and prednisolone $(10 \mathrm{ml}$ per day), or an alternative schedule of 10 or $25 \mathrm{mg}$ prednisolone every second day. For controls, the findings of SDS-electrophoresis were compared with the same kind of analysis of urines from 17 non-transplanted patients, suffering from chronic glomerulonephritits.

\section{Samples and SDS electrophoresis}

Four hour urine samples were collected under sterile conditions and submitted on the same day to SDS electrophoresis or

Tab. 1. Patients with the basic renal disease, chronic glomerulonephritis.

\begin{tabular}{l|l|l|l}
\cline { 2 - 4 } & Transplant patients & Transplant patients & Non-transplant patients \\
\hline Immunosuppressive therapy & corticosteroid + cyclosporin & azathioprine + prednisolone & none \\
\hline Number of patients & 17 & 16 & 17 \\
\hline Mean age (years) & $44.9 \pm 6.4$ & $46.9 \pm 12.6$ & $44.1 \pm 12.9$ \\
\hline $\begin{array}{l}\text { Mean time after } \\
\text { transplantation (years) }\end{array}$ & $1.6 \pm 0.5$ & $8.4 \pm 3.7$ & - \\
\hline \begin{tabular}{l} 
Observation time \\
\hline
\end{tabular} & 7 months in 1 to 4 weeks intervals & \\
\hline
\end{tabular}

Distribution (n) of proteinuric patterns among patients

\begin{tabular}{|c|c|c|c|}
\hline \multirow{2}{*}{$\frac{\text { Proteinuric pattern }}{\text { Physiological }}$} & & & \\
\hline & 12 & 7 & 4 \\
\hline $\begin{array}{l}\text { Glomerular } \\
\quad \text { selective } \\
\text { medium selective } \\
\text { non-selective }\end{array}$ & $\begin{array}{r}15 \\
7 \\
2\end{array}$ & $\begin{array}{l}5 \\
7 \\
5\end{array}$ & $\begin{array}{l}5 \\
4 \\
1\end{array}$ \\
\hline Tubular & 4 & 0 & 0 \\
\hline $\begin{array}{l}\text { Mixed } \\
\text { weak } \\
\text { medium } \\
\text { intensive }\end{array}$ & $\begin{array}{l}6 \\
7 \\
1\end{array}$ & $\begin{array}{l}0 . \\
3 \\
5\end{array}$ & $\begin{array}{l}0 \\
1 \\
7\end{array}$ \\
\hline
\end{tabular}


stored deep frozen $\left(-20^{\circ} \mathrm{C}\right)$ until analysed. Deep freezing did not affect the result of the SDS electrophoresis. No preservatives were added to samples and no concentration procedures were necessary.

An adapted horizontal SDS electrophoresis was used permitting simultaneous analysis of 22 samples as described elsewhere (11).

Evaluation of proteinuric pattern in the SDS electrophoresis

Table 2 shows a list of proteins found usually in pathological urine samples with their molecular weights. These data, reported in the literature $(10,12)$ were verified by our own immunoblotting experiments. According to their pathophysiological origin two groups of urinary proteins can be distinguished:

- glomerular proteins comprising albumin and proteins with $M_{\mathrm{r}}>67000$

- tubular proteins with $M_{\mathrm{r}}<67000$

Tab. 2 Urinary proteins

\begin{tabular}{ll}
\hline$M_{r}$ & Glomerular proteins \\
\hline 180000 & apolipoprotein A \\
150000 & immunoglobulin \\
130000 & polymeric albumin \\
77000 & transferrin \\
67000 & albumin \\
\hline$M_{r}$ & Tubular proteins \\
\hline 54000 & $\alpha_{1}$-antitrypsin \\
44000 & $\alpha_{2}$-acid glycoprotein \\
40000 & $\beta_{2}$-glycoprotein \\
21000 & retinol binding protein \\
15000 & lysozyme \\
11800 & $\beta_{2}$-microglobulin \\
\hline
\end{tabular}

We differentiated four main proteinuric patterns with some subdivisions:

1. physiological: total protein below $0.15 \mathrm{~g} / 1$

2. glomerular: containing only glomerular proteins subdivided into

- selective (containing only albumin)

- medium selective (containing only albumin and transferrin)

- non selective (containing albumin, transferrin and immunoglobulin)

3. tubular: containing albumin and proteins with $M_{\mathrm{r}}<67000$, with total protein $>0.15 \mathrm{~g} / \mathrm{l}$

4. mixed: proteinuric pattern, consisting of glomerular and tubular; according total protein subdivided into:

- weak (0.15 to $0.3 \mathrm{~g} / \mathrm{l}$ total protein)

- medium ( 0.3 to $1.0 \mathrm{~g} / 1$ total protein)

- intensive (more than $1.0 \mathrm{~g} / 1$ total protein)

\section{Results and Discussion}

Using the SDS electrophoresis we were able to monitor acute as well as chronic changes of kidney graft function.

\section{Case 1}

Figure 1 illustrates the time course of the pattern of urinary proteins, serum creatinine and total urinary protein of a 17 year old girl with diabetes type I. She received a kidney graft and developed acute rejection after 5 weeks ( 35 days). The proteinuric pattern changed within this time from "glomerular unselective" to "mixed intensive". The change of proteinuric pattern was accompanied by elevation of serum creatinine ( $28^{\text {th }}$ day), both observed 4 weeks before the definitive increases of total urinary protein ( $39^{\text {th }}$ day). On the $43^{\text {rd }}$ day the kidney graft was removed.

\section{Case 2}

In figure 2, the time course of the proteinuric pattern, serum creatinine and cyclosporin blood levels can be seen. A 35 year old man with chronic glomerulonephritis received a kidney graft under treatment with low doses of corticosteroids and cyclosporin. In the $10^{\text {th }}$ and $12^{\text {th }}$ week after transplantation two rejection episodes were observed, accompanied by a change of proteinuric pattern towards "mixed intensive". Later, after recovery after the $21^{\text {st }}$ week, a "tubular" proteinuric pattern was observed together with a continuous elevation of serum creatinine (up to $372 \mu \mathrm{mol} / 1$ in the $27^{\text {th }}$ week). Since the cyclosporin blood level was near the suggested upper therapeutic limit $(3,4)$ between the $24^{\text {th }}$ and $27^{\text {th }}$ week, we can interpret the occurrence of "tubular" proteinuria as a cumulative transient toxic effect of cyclosporin on tubular cells, as recently reported in patho-morphologic studies $(4,5,7)$.

Patients with chronic glomerulonephritis as a basic disease

Table 1 (bottom) indicates the results of SDS electrophoresis of urine samples during 7 months monitoring. Comparing the number of patients, in which different proteinuric patterns were found, we can see that two types were found exclusively in patients treated by low dose corticosteroids and cyclosporin:

- "tubular" (in 3 of 16 patients)

- "mixed weak" (in 8 of 16 patients) 

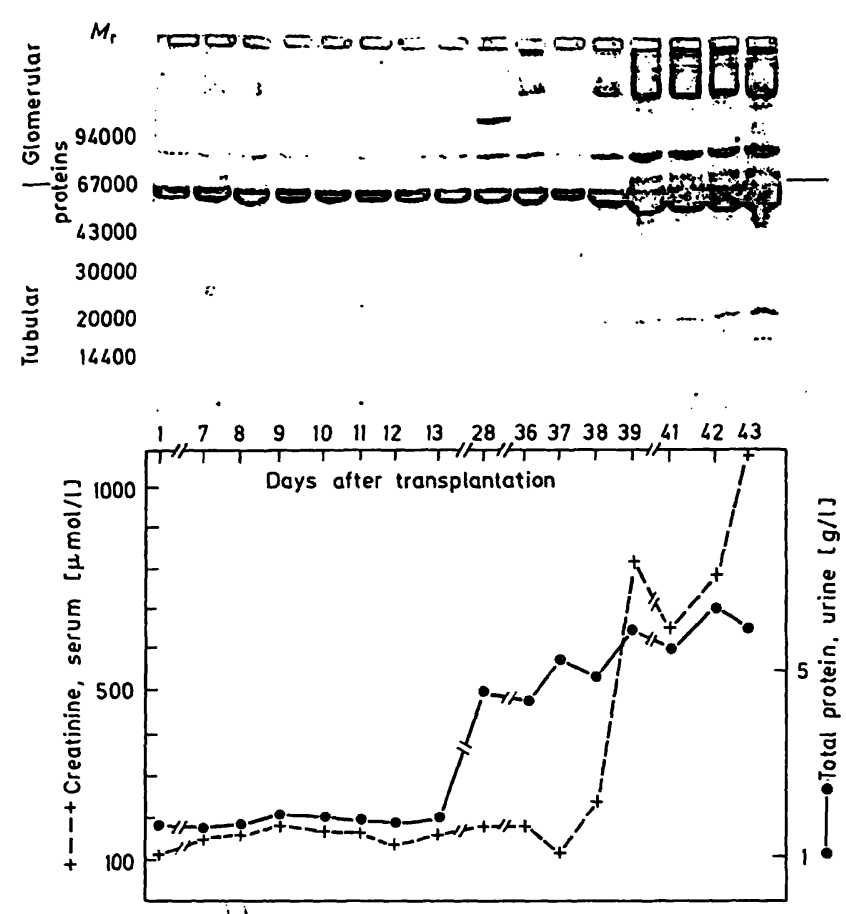

Fig. 1. A 17 year old kidney transplant girl with diabetes type I. Time course of proteinuric pattern (top) together with serum creatinine and total urinary protein (bottom).

The distribution of proteinuric types in patients treated by conventional therapy (azathioprine and prednisolone) is comparable to that of the control group of non transplant patients with chronic glomerulonephritis; moreover, tubular and mixed weak proteinuric types do not occur in these two groups. The results agree with recently postulated nephrotoxic effects of cyclosporine (7), where the tubule is believed to be the primary site of an injury that is initially reversible. Multiple injury of tubules then leads to degeneration of entire nephrons.

This pathogenetic mechanism seems to correlate with the SDS electrophoretic findings: tubular injury leads to low molecular weight proteins in the urine. Degeneration of a few entire nephrons can be seen as a cause of "mixed weak" proteinuria. In conclusion we can say that SDS electrophoresis of urinary proteins provides useful, plausible and illustrative information for the clinician, especially with regard the changing status of patient. In addition, the method is noninvasive.

Moreover, the diagnosis of tubular or glomerular proteinuria by SDS electrophoresis can be based entirely on the occurrence of a characteristic pattern of
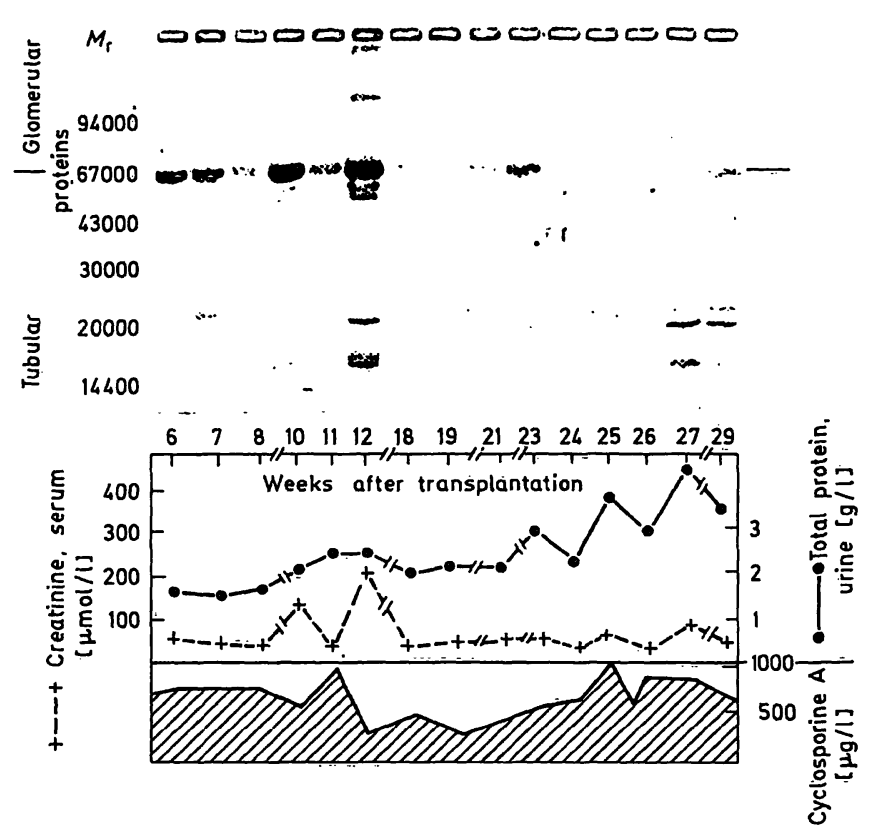

Fig. 2. A 35 year old man, with chronic glomerular nephritis as basic disease, receiving his first kidney graft. Time course of proteinuric pattern together with serum creatinine total urinary protein and blood level of cyclosporin.

urinary proteins. This can be seen as a main advantage in comparison with other methods, which measure a single parameter such as urinary $\beta$-2-microglobulin or certain enzymes. The widely used measurement of $\beta$-2-microglobulin as a marker for tubular damage is limited, because of its instability in acid urine samples (9). The measurement of enzymes in urine is useful for the diagnosis of tubular damage, but this measurement is of low significance in the differentiation between a rejection episode and cyclosporin toxicity in renal transplant patients.

According to our studies, SDS electrophoresis is a useful accessory diagnostic method for differentiating between kidney graft rejection and the nephrotoxic side effect of cyclosporin A.

\section{Acknowledgement}

We thank to Dr. Ch. Mannhalter for immunoblotting assays and Dr. J. Schindler for providing measurements of Cyclosporin $A$ in blood.

We are greatful to Mrs. $B$. Neidhard for preparing the manuscript. 


\section{References}

1. Canadian multicentre transplant study group (1983) $\mathbf{N}$. Engl. J. Med. 309, 809-815.

2. Beveridge, T. (1983) Transplant. Proc. $15,433-437$.

3. Bowers, L. D. \& Canafox, D. M. (1984) Ther. Drug Monit. 6, $142-147$.

4. Thiel, G., Harder, F., Lörtscher, R., Brünisholz, M., Landmann, J., Brunner, F., Follath, F., Wenke, M. \& Mihatsch, M. (1983) Klin. Wochenschr. 61, 991-1000.

5. Clane, R. Y., Thirn, S., McMaster, P., Craddoch, G. N., White, D. J. G., Evans, D. B., Dunn, D. C., Pentlow, B. D. \& Rolles, R. (1978) Lancet II, 1323-1327.

6. Klintmalm, G. B. G., Iwatsuki, S. \& Starzl, T. E. (1981) Lancet $I, 470-471$.
7. Myers, D. H., Ross, J., Newton, L., Luetscher, J. \& Perlroth, M. (1984) N. Engl. J. Med. 311, 699-705.

8. Taube, D. H., Williams, D. G., Hartley, B., Rudge, G. J., Neild, G. H., Cameron, J. S., Ogg, G. S. \& Welch, K. I. (1985) Lancet $I I, 171-174$.

9. Hardwicke, J. (1984) Clin. Nephrol. 21, 50-53.

10. Boesken, W. H. (1981) In: Electrophoresis' 81 (Allen, R. C. \& Arnaud, P., eds.) pp. 259-270, Walter de Gruyter \& Co, Berlin, New York.

11. Lapin, A., Ogunyemi, E. O., Zyman, H., Gabl, F. \& Zazgornik, J. (1985) J. Clin. Chem. Clin. Biochem. 23, 777-780.

12. Lubega, J. (1983) Clin. Chim. Acta 128, 151-168.

DDr. Alexander Lapin

Institut für Klinische Chemie und Laboratoriumsdiagnostik der Universität Wien Lazarettgasse 14 A-1090 Wien 
$\therefore \quad$ 